\title{
Hastanelerde Performans Değerleme Sisteminin Çalışan Motivasyonuna Etkileri Hakkında Çalışan Görüşıleri (Çankaya İlçesi Örneği) *
}

\section{Employee Opinions About the Effects of The Performance Appraisal System on Employee Motivation in Hospitals (Çankaya Sample)}

\author{
Prof. Dr. Zekai ÖZTÜRK (iD)1, Arş. Gör. Ece DOĞUÇ (iD)2
}

\begin{abstract}
$\ddot{O} z$
Günümüzde rekabet avantajını elde etmeyi hedefleyen işletmeler, en önemli girdi olan insan kaynaklarını en verimli şekilde kullanmalıdır. İnsan kaynaklarının ne kadar verimli ve etkin kullanıldığını açıklayan performans değerlendirme sistemi ve performansı etkileyen motivasyon işletmeler için hayati önem arz etmektedir. Bu nedenlerden dolayı bu araştırma insan kaynaklarının belki de en önemli unsur olduğu hastanelerde performans değerleme sisteminin işgören motivasyonuna etkisini açıklamayı amaçlamaktadır. Araştırmanın örneklemini Ankara Çankaya Bölgesinde hizmet vermekte olan bir üniversite, devlet ve özel hastanesinde görev yapan 462 çalışan oluşturmaktadır. Veri toplama aracı olarak performans değerlendirme sistemi ile motivasyonu ölçen iki ölçek kullanılmıştır. Elde edilen veriler analiz edilip yorumlanarak çalışma tamamlanmıştır. Çalışmada elde edilen veriler frekans, yüzde dağılımları, keşifsel faktör analizi, Kolmogorov Smirnov, Mann Whitney-U ve Kruskal Wallis testleri kullanılarak değerlendirilmiş ve yorumlanmıştır. Performans değerleme sistemi ve motivasyona analizler sonucunda iş görenlerin yaş grupları, unvan, çalışılan departman ve yöneticilik pozisyonunda olup olmama durumları ile performans değerleme sistemi ve motivasyona ilişkin görüşleri arasında farklılık bulunduğu görülmüştür. Aynı şekilde özel, kamu ve üniversite hastaneleri arasında hem performans hem de motivasyon açısından istatistiksel olarak anlamlı farklılı̆ıı bulunduğu sonucuna varılmıştır. Son olarak performans değerleme ile motivasyon arasında pozitif yönlü ve doğrusal bir ilişkinin olduğu tespit edilmiştir.
\end{abstract}

Anahtar Kelimeler: Performans, performans değerlendirme, motivasyon, sağlık çalışanları

Makale Türü: Araştırma

\begin{abstract}
Nowadays, businesses that aimed to gain competitive advantage, have to use human resources which is the most important input in the most efficent way. Performance evaluation system that explaines how efficiently and effectively human resources is used, and motivation that effects performance is vital for businesses. For these reasons, this research aims to clarify the effect of performance evaluation system to motivation in hospitals where human resoruces is perhaps the most important factor. The sample of the research consists of 462 employees from a university, government and private hospital serving in Çankaya Region of Ankara. Two scales are used that measure performance evaluation system and motivation as data collection tool. The research is completed by analyzing and interpreting the obtained data. Data obtained within the study is evaluated and interpreted by using frequency, percentage distributions, exploratory factor analysis, and Kolmogorov Smirnov, Mann Whitney-U and Kruskal Wallis tests. As a result of the analysis on the performance appraisal system and motivation, it is seen that there is a difference between

\footnotetext{
* Bu çalışma Gazi Üniversitesi Sosyal Bilimler Enstitüsü Hastane İşletmeciliği Bilim Dalında sunulan Yüksek Lisans Tezi’nden hazırlanmıştır.

${ }^{1}$ Ankara Hacı Bayram Veli Üniversitesi, İktisadi ve İdari Bilimler Fakültesi, zekai.ozturk@ hbv.edu.tr.

${ }^{2}$ Ankara Hacı Bayram Veli Üniversitesi, İktisadi ve İdari Bilimler Fakültesi, ece.doguc@hbv.edu.tr.
}

Atıf için (to cite): Öztürk, Z. ve Doğuç, E. (2020). Hastanelerde performans değerleme sisteminin çalışan motivasyonuna etkileri hakkında çalışan görüşleri (Çankaya İlçesi örneği). Afyon Kocatepe Üniversitesi Sosyal Bilimler Dergisi, 22(2), 519-536. 
the age groups, title, working department and managerial positions of the employees and the performance appraisal system and motivation views. Similarly, a statistically significant difference between private, public and university hospitals in terms of both performance and motivation is concluded. Finally, it is determined that there is a positive and linear relationship between performance appraisal and motivation.

Keywords: Performance, performance appraisal, motivation, healthstaff

Paper Type: Research

\section{Giriş}

Hızlı teknolojik değişimler ve Sanayi Devrimi ile birlikte işgücünde ihtisaslaşma çok artmış (Özgen vd., 2005, s. 5) ve geleneksel kaynaklar organizasyonları için temel rekabet avantajı olma özelliğini giderek kaybetmiştir (Filizöz, 2003, s. 165). Bu durum organizasyonları insan kaynakları başta olmak üzere daha yenilikçi kaynaklara yöneltmiştir (Armstrong, 2006, s. 4). Bugün birçok organizasyon, gelecekteki başarılarının anahtarının istihdam gücünde ve onların sahip olup kullandığ 1 bilgide olduğunu keşfetmiştir (Barutçugil, 2004, s. 18). Bu bilginin doğru ve etkili bir şekilde kullanıldığını gösteren performans değerleme kavramı ise bu bilgiler ışı̆̆ında önemli hale gelmiştir. Bir çalışanın; belirli bir standart ile beceri ve bilgi düzeyine göre ölçülen yeterlilik düzeyini tanımlamanın bir yolu (Shi, 2010, s. 12) olan performans değerleme ayrıca çalışanın işteki başarısını saptamak üzere kendisinden beklenenleri ne derece iyi gerçekleştiğini belirlemeye yönelik bir faaliyettir (İlsev, 2016, s. 177). Performans değerleme sonucunda ortaya konan sonuçlardan iş görenlere ait çeşitli ve önemli kararların alınmasında yararlanılır (Tortop vd., 2007, s. 280).

Motivasyon ise insan davranışlarını ve performansını etkileyen temel nedenlerden biridir (Özer ve Bakır, 2003, s. 117). Geniş anlamda baktığımızda, motivasyon bir bireyin çabasını ve bu çabanın yönü ile kararlılığını içermekte yani bireyi harekete geçiren karar verme gücü, bireyin iradesi olarak tanımlanabilmektedir (Brooks, 2006, s. 48). Eğer bir organizasyon; çalışanlarını neyin motive ettiğini biliyorsa, iyi performans göstermelerini teşvik etmek için daha iyi bir konum sahiptir. Çalışanların yüksek performans seviyelerine ulaşmaları için, işverenlerin çalışanları motive eden faktörleri bulmaları, anlamaları ve desteklemeleri gerekmektedir (Wiley, 1997, s. 276).

Hastanelerin de toplumun gereksindiği sağlık hizmetlerini karşılamak amaciyla faaliyet gösteren emek-yoğun teknolojiye sahip birer organizasyon olduğu düşünüldüğünde, belirlenen bir amaca ulaşmada, hastanenin başarısı ya da başarısızlığı çalışanlara bağlıdır (Özer ve Bakır, 2003, s. 118). Sağlık kurumlarında iş performansıyla ilgili akademik yazına bakıldığında performansı etkileyen etmenler için çok fazla çalışma yapılmadığı ve yapılan çalışmalarda ise tüm etmenlerin çalışmaya dahil edilerek analiz edilmediği görülmektedir. Bu kapsamda çalışma, özel ve kamu hastanelerinde görev yapan sağlık çalışanlarının hastanelerinde uygulanan performans değerleme sisteminin çalışan motivasyonlarına etkilerini ve bu konu hakkında çalışanların görüşlerini belirlemek ve performans değerleme sistemi ile çalışan motivasyonu arasındaki ilişkinin ortaya çıkarılması amaçlanmıştır.

\section{Literatür Taraması}

\subsection{Performans Değerleme Kavramı ve Önemi}

Performans değerleme ile genel olarak, bireysel, kurumsal ya da grupsal herhangi bir konuda etkinliğini bir grup özelliklere göre analiz etmeye ve başarılarını ölçmeye yönelik çalışmalar kastedilmektedir (Helvacı, 2002, s. 159). Performans değerleme çalışanların işlerinin gereklilikleri olan standartları iyi yapıp yapmadıklarını belirleme ve daha sonra bu bilgileri çalışanlara iletme sürecidir (Mathis ve Jackson, 2011, s. 320). Çalışanların verimliliği, iş performans1, işine olan ilgisi, yaptığı işe yönelik bilgi, beceri ve yeteneği ile kriz yönetim becerisinin ölçüldüğü performans değerleme faaliyetindeki temel hedef, örgütteki insan 
kaynaklarının mevcut potansiyelini artırmak ve örgütün stratejik gelişimini sağlamaktır (Camardella, 2003, s. 104).

Performans değerlemenin iki ana amacı vardır. $\mathrm{Bu}$ amaçlardan ilki, iş performansı hakkında bilgi edinebilmektir. Bu bilgiye yönetsel kararlar alınırken ihtiyaç duyulacaktır. Ücret artışları, ikramiyeler, eğitim, disiplin ve terfi gibi kararlar ve başka yönetsel kararlar büyük çoğunlukla performans değerlemeden elde edilen bilgilere dayanır. Performans değerlemesi yapmanın ikinci ana amacı ise; iş görenlerin iş tanımlarında ve iş analizlerinde saptanan standartlara ne kadar yaklaştığına dair geri besleme temin etmektir (Palmer, 1993, s. 9-10).

Özellikle sağlık sektöründe sağlık personeli, yaşlanan nüfusa, günümüzdeki hastalıklara ve kapsamlı pahalı biyomedikal teknolojiye atfedilen sağlik harcamalarının artması nedeniyle birçok konuda güçlü bir baskı altındadır (Aletras vd. 2007, s. 37). Sağlık kurumlarının sınırlı kaynaklar ile sağlıkı bir toplum yaratma baskısı (Öztürk vd. 2016, s. 623) ve aynı zamanda sağlık kurumlarının yüksek verimli ve etkili sağlı hizmetleri sağlama zorunluluğu yüzünden kurumlar oldukça zorlanmaktadır (Gu ve Itoh, 2016, s. 801). Bu zorluklar hemen hemen her ülkede kaynak kullanımını verimli hale getirebilecek olan performans kavramını denetlemeye ve geliştirmeye yönelik girişimlerin artmasına neden olmuştur. Sağlık kuruluşları maliyetleri düşürmek ve çıktıları iyileştirmek için performans ölçümü yapmak zorundadırlar. Daha açık bir ifadeyle; sağlık hizmetlerinde klinik kalitenin geliştirilmesi, ulaşılabilirliğin artırılması, maliyetlerin azaltılması, pazardaki rekabet, vb. sağlik sistemlerinde performansın izlenmesi ve ölçülmesini gerekli k1lmıştır (Scott vd., 2018, s. 123).

\subsection{Performans Değerleme Yöntemleri}

Değerlendirmeye ilişkin yöntemler; işin türüne, örgütlerin yapısına, yönetimin amacına, çalışanın beklentilerine, çevreye, teknolojik faktörlere ve işletmenin terfi planlarına göre değişebilmektedir. $\mathrm{Bu}$ nedenle, performans değerleme sürecinde seçilecek olan yöntemin işletmeye uygun olması, değerlendirme faaliyetlerinin başarısını önemli ölçüde etkilemektedir (William vd., 1996, s. 275). Bütün bu koşullara uygun bir değerleme yöntemi seçmek ve uygulamak organizasyonlar için oldukça zordur çünkü seçilen her yöntemin kendine özgü avantajları ve dezavantajları bulunmaktadır.

Çalışanların performanslarını ortaya koymak için geliştirilmiş birçok yöntem vardır. Bunlardan bazıları performans değerleme kavramının ilk uygulama örneklerinde kullanılmaya başlanmış ve günümüzde geleneksel olarak adlandırılabilecek yöntemlerdir. Diğer bir kısmı ise, klasik değerlendirme yöntemlerinde karşılaşılan sorunları ortadan kaldırabilmek ve performans değerleme faaliyetlerini daha objektif bir biçimde yapabilmek amaciyla geliştirilmiş olan modern yöntemlerdir. Klasik yöntemler, çalışanı görev ağırlıklı değerlendirme yaklaşımı ile ele almaktadırlar. Bu yöntemlerde, çalışanların işlerinde gösterdikleri başarıdan ziyade kişilikleri değerlendirilmektedir. Astların yönetime katılmasını amaçlayan modern yöntemler ise, bu süreçte çalışanın yaptığı işi başarma derecesinin yanı sıra, onun beklentilerini de göz önüne alan yaklaşımları içermektedir.

Performans değerleme yöntemleri kişilerarası karşılaştırmalara dayalı, ortak performans kriter ve standartlarına dayalı ve bireysel performans standartlarına dayalı yaklaşım olarak üç kategoriye ayrılmaktadır. Kişilerarası karşılaştırmaya dayalı yöntemler; sıralama ve zorunlu dağılım yöntemidir. Ortak performans kriter ve standartlarına dayalı yöntemler ise değerlendirme skalaları, kritik olay ve işaretleme listesi yöntemidir. Son olarak bireysel performans standartlarına dayalı yaklaşımda, direkt indeks, standartlar yöntemi ve amaçlara göre yönetim yer almaktadır. Performans değerlendirmesinde en yeni ve popüler yaklaşımlardan biri çok kaynaklı performans değerlendirmesi ve geribildirim kullanılmasıdır. 360 derece performans değerlendirme çalışan performansının onun etkileşim içinde olduğu tüm kişiler tarafından değerlendirilmesidir. Bu yöntemin amacı tüm açılardan bilgi sağlanarak daha sağlıkı bir değerlendirmenin yapılması ve çalışanın performansını daha geniş bir açıdan görmesidir (İlsev, 2016, s. 185). 
Organizasyonlarda, performans değerlemenin çok duyarlı bir konu olduğu göz önünde bulundurulmalı, değerleme yönteminin seçiminden uygulanmasına kadar son derece titiz davranılmalı, elde edilen sonuçlar yakından denetlenmeli, uygulanan yöntemde aksamalar varsa bunları zamanında giderici etkili önlemler alınmalı ve her şeyden önemlisi değerlemenin bir cezalandırma aracı değil, tersine çalışanların eksik yönlerini tamamlayıcı, onların yetişme ve yükselmelerine yardımcı bir teknik olarak algılanması sağlanmalıdır (Sabuncuoğlu, 2005, s. 217).

\subsection{Motivasyon Kavramı ve Önemi}

Motivasyon, davranışın gücü ve yönü ile insanları belirli şekillerde davranmak için etkileyen faktörler ile ilgilidir (Armstrong, 2010, s. 136). Motivasyon, insan davranışlarını açılayan teorik bir yapıdır. İnsanların eylemleri, arzuları ve ihtiyaçları için nedenler verir ve aynı zamanda kişinin davranışa yönelmesi olarak veya bir kişinin bir davranışını tekrar etmesini isteyen şeyin nedeni olarak ya da tam tersi olarak da tanımlanabilir (Elliot ve Covington, 2001, s. 73). İş motivasyonu ise işyerinde harcanan çabanın seviyesini, yönünü ve ısrarını hesaba katan bir kişinin içindeki güçleri ifade eder (Schermerhorn vd., 2002, s. 147). İnsan çok yönlü ve benzeri olmayan bir varlık olması açısından oldukça karmaşık bir yapıya sahiptir. Konuya örgüt açısından bakıldığında ise, örgüt amaçları ile iş gören amaçlarının çoğu zaman çelişkili durumlar yarattığı görülmektedir (Argon ve Eren; 2004, s. 115). Bu gibi durumları ortadan kaldırmak ya da minimuma indirmek için bireysel amaçlar ile örgütsel amaçların entegrasyonunu sağlamak gerekmektedir.

Motivasyonun; örgütsel davranış, yönetim ve örgüt psikolojisi alanlarında tarihsel bakımdan önemli bir kavram olduğu görülmektedir. Kavram, farklı yönetim anlayışlarına göre değişik açılardan ele alınmakta ve değerlendirilmektedir. İnsan kaynakları yaklaşımında ise, motivasyon konusunda bütüncül bir bakış açısı ortaya konmaktadır (Gök, 2009, s. 591). Doğru yönde motive olmuş bir iş gören, yöneticisinin gözetimine gerek kalmaksızın müşteriyi tatmin etmek için çalışır, süreci iyileştirmek için teklifler sunarak önemli bir rekabet avantajı sağlayabilir (Hiriyappa, 2008, s. 144). Motivasyon, iş verimliliğini artırmada çok önemli bir unsurdur; her yöneticinin, iş doyumu ve ödül sistemleri ile nasıl ilişkili olduğu konusunda sağlam bir anlayışa sahip olmas1 gerekir (Pardee, 1990, s. 2).

\subsection{Motivasyon Faktörleri ve Araçları}

Çalışan motivasyonunda etkili olan faktörlerin başlıca iki bakış açısına dayandırılarak açıklamaya çalışıldığı görülmektedir. Bunlardan biri çalışanların dışsal faktörler tarafindan motive edildiği görüşüdür. Diğeri ise sosyal ve parasal yararlar kadar kendi bireysel amaçları daha iyi çalışarak içsel olarak motive olacağı görüşüdür (Kılıç ve Keklik, 2012, s. 149). Bu ayrımın aslını bir kişinin kendini güdülerine göre motive edebileceği ya da tam tersi dışarıdan gelecek isteklendirmeler ile harekete geçebileceği iddiaları oluşturmaktadır (Wiersma, 1992, s. 102).

Bugüne kadar sunulan veya uygulanan motivasyon model ve araçların tam bir başarıya ulaştığı söylenemez. Yöneticiler için en önemli sorun, ayrı ayrı gereksinim ve kişiliklere sahip olan çalışanlar için, amaçlara yaklaştırıcı, inandırıcı ve özendirici motivasyon araçlarına sahip olmaktır. Çünkü insanları motive eden unsurlar kişiden kişiye farklılık göstermekte ve sürekli değişmektedir (Ölçer, 2005, s. 3). Çalışanları iş yapmaya yönelten en kuvvetli motivasyon özendiricileri ekonomik araçlardır. Bu araçlar ise; ücret artışı, kara katılma, ekonomik ödül, prim, sosyal yardımlar/kolaylıklar gibi sıralanabilir (Kılıç ve Keklik, 2012, s. 149). Motivasyon araçları içinde psiko-sosyal araçların önemi büyüktür (Alkış, 2008, s. 83) ve bireylerin içsel yapılarındaki ihtiyaçlarını çalışmada bağımsızlık, sosyal katılma, değer ve statü gibi faktörler ile karşılanabilmektedir (Bayrakçı, 2010, s. 17). Örgütsel-yönetsel araçlar çalışanların örgütle bütünleşmesini sağlayan araçlardır ve motivasyon sürecinde yararlanılan örgütsel-yönetsel araçlar; kararlara katılım, yetki devri, amaç birliği sağlama, eğitim ve yükselme olanakları, iletişim, iş güvencesi, katılımcı ve demokratik yönetim, etkin önderlik olarak sıralanabilir. (Tarakçığlu vd., 2010, s. 5). 
Motivasyon konusunda psikologlar birçok teori geliştirmiştir. Ancak bu kuramların hiçbiri tam ve evrensel anlamda benimsenebilecek düzeyde değildir. Her kuram insan davranışlarının nedenlerini diğerlerinden farklı varsayımlara dayandırmakta ve sonuçta doyurucu bir model sunmaktan uzak bulunmaktadır (Can vd. 2009, s. 366). Motivasyon kuramları, kapsam (geleneksel) ve süreç (modern) olmak üzere iki başlık altında incelenmektedir (Tablo 1.).

Tablo 1. Kapsam ve süreç kuramlarını genel bir bakış

\begin{tabular}{|c|c|c|c|}
\hline Tür & Kuram & Temel Varsayım & Uygulamactlara Katkıst \\
\hline \multirow[t]{5}{*}{$\begin{array}{l}\text { Kapsam Kuramları: } \\
\text { bireylerin ne şekilde } \\
\text { motive edildiğine } \\
\text { odaklanır. }\end{array}$} & $\begin{array}{l}\text { İhtiyaçlar Hiyerarşisi Kuramı } \\
\text { - Maslow }\end{array}$ & $\begin{array}{l}\text { Bireyin yaptığ her davranış, } \\
\text { belirli ihtiyaçları gidermeye } \\
\text { yöneliktir ve beş kademe } \\
\text { ihtiyaç vardır. }\end{array}$ & $\begin{array}{l}\text { Bireyleri örgüt amaçları } \\
\text { doğrultusunda motive edilmeleri } \\
\text { için neler yapılması gerektiğini } \\
\text { göstermektedir. }\end{array}$ \\
\hline & X ve Y Kuramı - Mc Gregor & 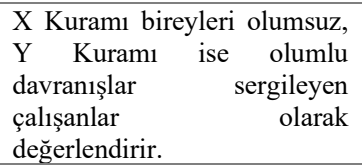 & $\begin{array}{l}\text { Yöneticiler } \\
\text { farklılıklarını analiz ederek } \\
\text { yönetim şekillerini ona göre } \\
\text { düzenlemelidir. }\end{array}$ \\
\hline & $\begin{array}{l}\text { Çift Faktör Kuramı (Hijyen- } \\
\text { Motivasyon Kuramı) - } \\
\text { Herzberg }\end{array}$ & $\begin{array}{l}\text { Bireylerin motive olması için } \\
\text { bulunması gereken asgari } \\
\text { koşullar Hijyen Faktörü } \\
\text { altında ele alınmaktadır. }\end{array}$ & $\begin{array}{l}\text { Örgütteki bireylerin sadece hijyen } \\
\text { ya da sadece motivasyon } \\
\text { faktörlerinin tatmin edilmesi ile } \\
\text { başarıya ulaştırılması mümkün } \\
\text { değildir. Yöneticiler her iki } \\
\text { faktörü de göz önüne almalıdır. }\end{array}$ \\
\hline & $\begin{array}{l}\text { Başarma İhtiyaç Kuramı - } \\
\text { McClelland }\end{array}$ & $\begin{array}{l}\text { Başarma, güç kazanma ve } \\
\text { ilişki kurma ihtiyaçlarından } \\
\text { oluşmaktadır. }\end{array}$ & $\begin{array}{l}\text { Başarma ihtiyacı kuvvetli olan } \\
\text { bireyler, kendilerine yüksek } \\
\text { hedefler koyarlar. Yöneticilerin } \\
\text { çalışanları iyi yönlendirmeleri } \\
\text { gerekir. }\end{array}$ \\
\hline & ERG Kuram1 - Alderfer & $\begin{array}{l}\text { Var olma, ait olma ve gelişme } \\
\text { ihtiyacından oluşur. }\end{array}$ & $\begin{array}{l}\text { Yöneticiler ihtiyaçları tatmin } \\
\text { ettikçe bireyler daha çok } \\
\text { performans göstermektedir. }\end{array}$ \\
\hline \multirow{5}{*}{$\begin{array}{l}\text { Süreç kuramları: } \\
\text { durağan çevre } \\
\text { koşulları } \\
\text { varsayımından hareket } \\
\text { ederek, iş } \\
\text { motivasyonun dinamik } \\
\text { bir süreç içerisinde } \\
\text { gerçekleştiğini } \\
\text { savunmaktadır. }\end{array}$} & $\begin{array}{l}\text { Koşullanma } \quad \text { Kuramı } \\
\text { Skinner }\end{array}$ & $\begin{array}{lr}\text { Öğrenme davranışın } & \text { bir } \\
\text { sonucu } & \text { olarak } \\
\text { gerçekleşmektedir. } & \text { Çevre } \\
\text { tarafindan } & \text { benimsenen } \\
\text { davranışlar } & \text { tekrar } \\
\text { edilmektedir. } & \\
\end{array}$ & $\begin{array}{l}\text { Yöneticiler çalışanlarına sık sık } \\
\text { geribildirimlerde bulunursa, } \\
\text { onları olumlu davranışlara } \\
\text { yönlendirmiş ve motivasyonlarını } \\
\text { da arttırmış olacaklardır. }\end{array}$ \\
\hline & Beklenti Kuramı - Vroom & $\begin{array}{l}\text { Bireyini belli bir iş için gayret } \\
\text { sarf etmesi, valens, bekleyiş } \\
\text { ve araçsallığa bağlıdır. }\end{array}$ & $\begin{array}{ll}\text { Davranış-sonuç } & \text { ilişkisi geliştiren } \\
\text { çalışanların } & \text { beklentileri } \\
\text { karşılandıkça işe } & \text { bağlllıkları } \\
\text { artacak ve daha iyi } & \text { performans } \\
\text { göstereceklerdir. } & \end{array}$ \\
\hline & Lawyer- Porter Modeli & $\begin{array}{l}\text { Bireyi motive eden faktör } \\
\text { içsel ve dışsal ödüllerdir. }\end{array}$ & $\begin{array}{l}\text { Yönetici dışsal faktörlere dikkat } \\
\text { ederek çalışanın demoralize } \\
\text { olmasını engellemelidir. }\end{array}$ \\
\hline & Eşitlik Kuramı - Adams & $\begin{array}{lr}\text { Örgütlerdeki } & \text { eşitsizlik } \\
\text { algılarının } & \text { çalışanlar } \\
\text { üzerindeki } & \text { etkilerinin, iş } \\
\text { verimliliğgine ne şekilde } \\
\text { yansıdığını tartışmaktadır. }\end{array}$ & $\begin{array}{l}\text { Yönetici her çalışanına eşit } \\
\text { şartlarda davrandığını ortaya } \\
\text { koyduğunda tüm çalışanların } \\
\text { motivasyonları yüksek olacaktır. }\end{array}$ \\
\hline & Amaç Kuramı - Locke & $\begin{array}{l}\text { Bireylerin amaçları örgütteki } \\
\text { motivasyonları açısından } \\
\text { temel belirleyicidir. }\end{array}$ & $\begin{array}{lr}\text { Yöneticiler } & \text { çalışanların } \\
\text { hedeflerini } & \text { yükselterek, } \\
\text { performanslarını artırmalıdır. }\end{array}$ \\
\hline
\end{tabular}

Kaynak: Paşamehmetoğlu A. ve Yeloğlu H.O., 2016, s. 141-142.

\subsection{Performans Değerlemenin İş gören Motivasyonuna Etkisi ve Sağlık Sektöründe Etkileri}

Performans ve motivasyon arasında pozitif geri bildirim ilişkisi vardır. Performans değerleme, yönetim sistemi içerisinde değerlendirme safhası ve sonrasındaki süreç içerisinde motivasyonu etkilemektedir (Berdud vd. 2016, s. 412). Çalışan motivasyonu hem çalışanın hem de örgütün performansını etkilediği için iş hayatının önemli konuları arasında yer almaktadır. Motivasyonu düşük iş görenin olumlu performans sergilemesi beklenemez. İş motivasyonun kullanılmasının ana amacı organizasyon hedeflerinin gerçekleştirilmesi için çalışanın yüksek derecede performans göstermesine olanak sağlamaktır (Ağırbaş vd., 2005, s. 328). Esasen motive 
edici bir süreç olarak performans değerleme, bireyin kendi performansına ilişkin algısı, bu algıyla orantılı olan geribildirim beklentisi ve bilgilendirmeyle elde ettiği sonuçların beklentileriyle uyumlu olup olmadığıyla yakından ilgilidir (Argon ve Eren, 2004, s. 241). Performans değerlendirme doğru ölçütlerle, etkin ve adil olarak yürütüldüğünde organizasyon çalışanları üzerinde motive edici bir güce sahip olmakla kalmayacak, özellikle sağlık kurumları için önemli bir sorun olan devamsızlık, işgücü devri sorunların azalmasında da büyük etkiye sahip olacaktır (Karahan ve Özgür, 2011, s. 98). Performansı artırmak ve böylece organizasyonun etkililiğini artırmak için, insanlar davranışlarını değiştirmeleri için, enerjiyi eyleme nasıl ayıracağını değiştirmelidir, yani motivasyonlarını değiştirmelidirler. Doğru unsurların doğru şekilde değiştirilmesi, daha iyi performansa yol açar. Başka bir deyişle motivasyonu değiştirmeden davranışı ve sonunda performansı değiştirmek mümkün değildir (Pritchard ve Ashwood, $2008 \mathrm{~s}$. 6-7).

Sağlik sektörü emek yoğun olan hizmet sektördür ve gelişmekte olan ülkelerde sağllk insan gücü çoğu zaman hakkettiğinin altında bir ücret kazanır ve bu da çalışan motivasyonun bozulmasına neden olur. Ancak yeterli sağlık işgücü gelişimi, verimli ve iyi işleyen bir sağlık sisteminin temel işlevlerinden biridir. Sağlık insan gücü, iyi eğitimli, motive ve eşit şekilde dağıtılmış sağlık iş gücünden oluşmalıdır. İşgücü motivasyonu, sağlık sektörü performansı, verimliliği, hizmet kalitesi ve eşitlik için önemli bir belirleyicidir (Shah vd. 2016, s .468).

\section{Yöntem}

\subsection{Araştırmanın Amacı ve Önemi}

Araştırmanın amacı, özel ve kamu hastanelerinde görev yapan sağlık çalışanlarının hastanelerinde uygulanan performans değerleme sisteminin çalışan motivasyonlarına etkilerini ve bu konu hakkında çalışanların görüşlerini ortaya koymaktır. Ayrıca performans değerleme sistemleri farklı olan bu hastanelerin çalışanlarının görüşleri ve yine çalışanların verimliliklerinde önemli bir faktör olan motivasyonun algılanış biçiminin çalışanlar arasında farklılık olup olmadığını ortaya çıkarmaktır.

Bir örgütte çalışanların motivasyonun yüksek düzeyde olması verimliliklerini artırır varsayımından hareketle çalışanları motive eden faktörlerin ortaya çıkarılması ve bu yönde uygulamaların yapılması örgütün saygınlığ1 ve karlılığı açısından önem arz etmektedir. Bir örgütte performans değerleme sisteminin gereği gibi kurulmuş ve uygulanıyor olması motivasyonu olumlu yönde etkilemektedir. Bu çalışma kamu ve özel hastanelerde var olan personel değerleme sistemlerinin çalışan motivasyonuna etkilerini saptamak açısından önemli bir çalışmadır. Ayrıca bu çalışma bu alanda daha sonra yapılacak olan benzer çalışmalara veri teşkil edeceğinden önem arz etmektedir.

Araştırmada test edilen hipotezler aşağıda verilmiştir.

H1: Çalışanların performans değerleme sistemlerine ilişkin görüşleri demografik özelliklerine göre farkl111k göstermektedir.

H2: Çalışanların motivasyonları demografik özelliklerine göre farklılık göstermektedir.

H3: Performans değerleme boyutlarına ilişkin çalışan görüşleri kamu, özel ve üniversite hastaneleri arasında farkl1lık göstermektedir.

H4: Motivasyon boyutlarına ilişkin çalışan görüşleri kamu, özel ve üniversite hastaneleri arasında farkl11ı göstermektedir.

H5: Performans değerleme boyutları ile motivasyon boyutları arasında bir ilişki vardır. 


\subsection{Araştırmanın Evren, Örneklem ve Soru Kağıdının Hazırlanması}

Çalışmada ana kütleyi, Araştırma kapsamına alınan bir üniversite hastanesi, bir devlet hastanesi ve bir özel hastanede çalışan personel alınmış ve veriler toplanmıştır. Örneklem aşağıdaki formüller ile hesaplanmıştır (Büyüköztürk vd., 2016, s. 96):

$n=\frac{n_{0}}{1+\frac{n_{0}-1}{N}}$

$n_{0}=\left(t^{2} P Q\right) / d^{2}$

$\mathrm{N}$ : Hedef kitledeki birey sayıs

$n_{0}$ : Örnekleme alınacak birey sayıs 1

p: İncelenen olayın görülüşs sıklı̆̆ (gerçekleşme olasılığ 1 )

q: İncelenen olayın görülmeyişs sılılğ (gerçekleşmeme olasıllı̆ı)

t: Belirli bir anlamlılık düzeyinde, $t$ tablosuna göre bulunan teorik değer

d: Olayın görülüşs sıklığına göre kabul edilen örnekleme hatasıdır.

Araştırmada örnek çapını en büyük yapmak için $p+q=1$ şartını sağlamak koşuluyla $\mathrm{p}=\mathrm{q}=0.5$ alınmıştır. Formülde değerler yerine konduğunda toplamda 2090 çalışan için örneklem büyüklüğü 326 bulunmuştur. Ana kütlenin büyüklüğü göz önüne alındığında ve kurumlar arasında karşılaştırma yapılacağından anket uygulamasında ve çalışanlara ulaşılmasında Tabakalı Rastgele Örnekleme Yöntemi ile hangi kurumdan kaç tane anket alınacağı belirlenmiş ve sayılara uygun basit rastgele çalışanlar seçilerek anket uygulanmıştır. Ankara'da 1590 çalışanı olan üniversite hastanesi çalışmanın \%76'sını oluşturmuş ve 247 çalışan seçilmesi kararlaştırılmış çalışmaya 270 çalışan katılmıştır. Çalışan sayısı 300 olan ve örneklemin \%14'ünü oluşturan devlet hastanesinden katılması gereken kişi sayısı 46 bulunmuş, çalışma 100 kişi ile tamamlanmıştır. Son olarak 200 çalışana sahip olan özel hastane çalışmanın \%10'ünü oluşturmakta ve 33 olması gereken katılım 92 kişi ile tamamlanmıştır.

Araştırma da kullanılan anket formunun uygulanabilmesi için Gazi Üniversitesi Etik Kurulu (15.11.2016-E.137171 say1l izin) ve uygulama yapılan hastanelerden gerekli izinler alınmıştır. Performans değerlememeye ilişkin tutum ile motivasyon ölçülürken; Sultan Nuray Çağan (2012) ve Gülen Ergin (2012) tarafından yüksek lisans tezlerinde kullanılan ve geçerlilik ve güvenilirlikleri kanıtlanmış ayrıca çalışmanın amacına ile uyumlu olduğu görülen ölçekler kullanılmıştır. İlk bölümde katılımcıların sosyo-demografik özellikleri, ikinci bölümde performans değerlemeye ilişkin 27 soru ve son bölümde iş motivasyonuna (içsel ve dişsal motivasyon) ilişkin 24 soru sorulmuştur. Anketin birinci ve ikinci bölümü olan bütün performans değerleme ve içsel ve dışsal motivasyon ifadeleri için Cronbach Alpha değeri hesaplanmıştır. Performans değerleme anketi için Cronbach's Alpha katsayısı 0,945, içsel motivasyon anketi için Cronbach's Alpha katsayısı 0,865 ve dişsal motivasyon için Cronbach's Alpha katsayısı 0,870 olarak bulunmuş ve ölçeğin güvenilir olduğu sonucuna varılmıştır.

\subsection{Verilerin Analiz Yöntemi}

Araştırma sonucunda elde edilen 462 anketteki cevaplar bilgisayar ortamına aktarılmış ve istatiksel analizler bir istatistik paket program aracılığıyla yapılmıştır. Çalışmada uygulanan istatistiksel testler şunlardır: Ölçek ifadelerinin değerlendirilmesine ilişkin frekans analizi, açıklayıcı faktör analizi, güvenirlik analizi yapılmışır. Araştırma kapsamında sunulan hipotezlerin test edilmesi aşamasında öncelikle verilerin normal dağılıma uygunluğunu belirlemek için Tek Örneklem Kolmogorov Smirnov Testi anlamlılık değerine bakılmış, test anlamlılık değeri 0,000 bulunmuş ve verilerin normal dağılmadığı görülmüş bunun sonucunda parametrik olmayan test yöntemlerinin kullanılmasına karar verilmiştir. Verilerin normal dağılım göstermediği tespit edildiği için parametrik olmayan iki bağımsız grubun karşılaştırılmasında Mann Whitney-U Testi, ikiden fazla bağımsız grubun karşılaştırılmasında ise Kruskal Wallis testleri kullanılmıştır. Son olarak da Spearman's rho Korelasyon testi ile performans değerleme 
ile motivasyon boyutlarının ilişkileri incelenmiştir. Elde edilen bulgular \%95 güven aralığında, $\% 5$ anlamlılık düzeyinde değerlendirilmiştir.

\section{Bulgular}

Öncelikle araştırma sonucu elde edilen bulguları değerlendirmek için araştırmaya katılan 462 kişinin demografik verileri Tablo 2'de sunulmuştur.

Tablo 2. Katılımcıların demografik değişkenlere ilişkin dağılımları

\begin{tabular}{|c|c|c|c|}
\hline & \multirow{2}{*}{ Özellikler } & \multicolumn{2}{|c|}{ Örneklem } \\
\hline & & $\mathbf{N}$ & $(\%)$ \\
\hline \multirow{2}{*}{ Cinsiyet } & Kadın & 314 & 68,0 \\
\hline & Erkek & 148 & 32,0 \\
\hline \multirow{5}{*}{ Yaş } & 25 yaş altı & 61 & 13,2 \\
\hline & $26-35$ yaş & 163 & 35,3 \\
\hline & $36-45$ yas & 158 & 34,2 \\
\hline & $46-55$ yaş & 67 & 14,5 \\
\hline & $56-65$ yaş & 13 & 2,8 \\
\hline \multirow{4}{*}{ Eğitim Durumu } & Lise & 155 & 33,4 \\
\hline & Lisans-Ön lisans & 239 & 51,5 \\
\hline & Yüksek Lisans & 49 & 10,6 \\
\hline & Doktora & 19 & 4,1 \\
\hline \multirow{5}{*}{ Unvan } & Hekim & 66 & 14,3 \\
\hline & Hemşire & 104 & 22,5 \\
\hline & İdari Personel & 79 & 17,1 \\
\hline & Sağlık Teknikeri & 53 & 11,5 \\
\hline & Veri Hazırlama Kontrol İșletmeni & 160 & 34,6 \\
\hline \multirow{3}{*}{ Çalışılan Departman } & İdari Ve Mali Hizmetler & 226 & 45,4 \\
\hline & Laboratuvar Ve Görüntüleme Hizmetleri & 53 & 10,6 \\
\hline & T1bbi Hizmetler & 219 & 44,0 \\
\hline \multirow{5}{*}{ Meslekte Çalışma Süresi } & $1-5$ y1l & 131 & 28,4 \\
\hline & $6-10$ y1l & 88 & 19,0 \\
\hline & $11-15$ yil & 85 & 18,4 \\
\hline & $16-20$ yil & 68 & 14,7 \\
\hline & 21 y1l üzeri & 90 & 19,5 \\
\hline \multirow{2}{*}{ Yöneticilik } & Yöneticilik görevi var & 44 & 0,10 \\
\hline & Yöneticilik görevi yok & 418 & 0,90 \\
\hline Toplam & & 462 & 100 \\
\hline
\end{tabular}

Çalışanların demografik özellikleri incelendiğinde; katılımcıların \%68'inin kadın, \%32'sinin erkek olduğu görülmektedir. Hastaneler çoğunluğu kadınlardan oluşan kurumlar olduğu göz önüne alındığında bu durum normal görülmüştür. Katılımcıların \%69,5'i 26-45 yaş arasındadır. Katılımcıların eğitim düzeylerine bakıldığında, \%33,3’ü lise mezunu, \%51,9’u lisans ve ön lisans mezunudur. Örneklemin unvanlara göre dağılımları incelendiğinde hemşireler $(\% 22,5)$, idari personel $(\% 17,1)$ ve veri hazırlama kontrol işletmenleri $(\% 34,6)$ büyük çoğunluğunu oluşturmaktadır. Katılımcıların \%45,6's1 idari ve mali hizmetlerde, \%10,6's1 laboratuvar ve görüntüleme hizmetlerinde ve son olarak \%44'ü tıbbi hizmetlerde görev yapmaktadır. Meslekte çalışma sürelerine bakıldığında ise 1-5 sene arasında çalışanlar \%28,4'ünü, 6-15 sene arasında çalışanlar \%37,4'ünü, 11-20 sene arasında çalışanlar \%33,1'ini ve 21 ve üzeri sene çalışanlar \%19,1'ini oluşturmaktadır. Kurumda çalışma süresine bakıldığında ise 1-10 sene arasında çalışanlar \%62,9 ile büyük çoğunluktadır.

Performans değerleme ölçeği için ifadelerin frekanslarına ve ortalamalarına bakıldığında çalışanların katılım düzeylerinin en yüksek olduğu ifadeler "Organizasyonun hedeflerine ulaşmasında üzerime düşeni biliyorum." $(\bar{x}=3,961)$, "Yöneticim işimle ilgili aksaklıkları zamanında iletir." $(\bar{x}=3,764)$ ve "İşyerimdeki görevim tam olarak belirlenmiştir." $(\bar{x}=3,623)$ olmuştur. Katılım düzeyinin en düşük olduğu ifadeler ise "İ̧̧yerim için ödüllendirme sadece ücrete yönelik değildir; sosyal imkânlarda ödül olarak sunulabilmektedir." $(\bar{x}=2,292)$ ve "Performansımdaki değişikliği ücretimde hemen izleyebilirim" $(\bar{x}=2,381)$ olmuştur. Motivasyon anketinde ise çalışanların katılım düzeylerinin en yüksek olduğu motivasyon ifadelerinin "Yaptığım işte başarılıyım." ( $\bar{x}=4,312)$ ve "Yaptığım işle ilgili olarak sorumluluğa sahibim." $(\bar{x}=4,294)$ olduğu tespit edilmiştir. Dişsal motivasyon ifadeleri içerisinde yer alan 
"Başarılarımdan dolayı ekstra ücret alırım." $(\bar{x}=2,058)$ ve "Başarılarımdan dolayı ödüllendirilirim." ( $\bar{x}=2,238)$ ifadeleri ise katılımın en düşük olduğu ifadelerdir.

Hipotez testlerinin yapılmasından önce performans değerleme ve motivasyon ölçeğinde yer alan ifadelerin anlamlı faktörler haline getirilip sadeleştirilmesi için Keşfedici Faktör Analizi gerçekleştirilmiştir. On faktörlü bir yapıya ulaşılmış olup bu faktörler performans değerleme için; değerleme sistemi, değerleme standartları ve hedefleri, değerleme sonrası geribildirim, değerlemeye bağlı ücret ve ödül ve iş dizaynı olmuştur. Motivasyon ölçeğinin faktörleri ise; içsel motivasyon için kendini değerli hissetme, örgütsel bağlllık iken dişsal motivasyon; ücret ve ödüllendirme, takım çalışması ve çalışma ortamının fiziki durumu olarak belirlenmiştir. Performans değerleme sistemine ve çalışan motivasyonuna ilişkin yapılan analizler sonucunda istatistiki anlamda farklılık gösteren çalışanların unvanları, departmanları, yöneticilik görevlerinin olup olmaması ve çalıştıkları hastaneler ile ilgili sonuçlar aşağıda gösterilmiştir.

Tablo 3. Performans değerleme algısı - unvan ilişkisi

\begin{tabular}{|c|c|c|c|c|c|c|}
\hline & Unvan & $\mathrm{N}$ & $\begin{array}{l}\text { Ortalama } \\
\text { Siras }\end{array}$ & $\begin{array}{c}\text { Serbestlik } \\
\text { derecesi }\end{array}$ & Ki kare & Sign \\
\hline \multirow{5}{*}{ Değerleme Süreci } & Hekim & 66 & 230,28 & \multirow{5}{*}{4} & \multirow{5}{*}{17,711} & \multirow{5}{*}{,001 } \\
\hline & Hemşire & 104 & 264,45 & & & \\
\hline & İdari personel & 79 & 253,11 & & & \\
\hline & Sağlık teknikeri & 53 & 232,94 & & & \\
\hline & VHKİ & 160 & 199,43 & & & \\
\hline \multirow{5}{*}{$\begin{array}{c}\text { Değerleme Standartları ve } \\
\text { Hedefleri }\end{array}$} & Hekim & 66 & 199,71 & \multirow{5}{*}{4} & \multirow{5}{*}{9,423} & \multirow{5}{*}{, 051} \\
\hline & Hemşire & 104 & 246,14 & & & \\
\hline & İdari personel & 79 & 237,35 & & & \\
\hline & Sağlık teknikeri & 53 & 264,77 & & & \\
\hline & VHKİ & 160 & 221,19 & & & \\
\hline \multirow{5}{*}{$\begin{array}{l}\text { Değerleme Sonrası } \\
\text { Geribildirim }\end{array}$} & Hekim & 66 & 250,64 & \multirow{5}{*}{4} & \multirow{5}{*}{6,943} & \multirow{5}{*}{, 139} \\
\hline & Hemşire & 104 & 244,97 & & & \\
\hline & İdari personel & 79 & 244,87 & & & \\
\hline & Sağlık teknikeri & 53 & 217,23 & & & \\
\hline & VHKİ & 160 & 212,98 & & & \\
\hline \multirow{5}{*}{$\begin{array}{l}\text { Değerlemeye Bağlı Ücret ve } \\
\text { Ödül }\end{array}$} & Hekim & 66 & 219,17 & \multirow{5}{*}{4} & \multirow{5}{*}{10,431} & \multirow{5}{*}{, 034} \\
\hline & Hemşire & 104 & 256,38 & & & \\
\hline & İdari personel & 79 & 233,42 & & & \\
\hline & Sağlık teknikeri & 53 & 258,74 & & & \\
\hline & VHKİ & 160 & 210,44 & & & \\
\hline \multirow{5}{*}{ İş Dizaynı } & Hekim & 66 & 236,05 & \multirow{5}{*}{4} & \multirow{5}{*}{,958 } & \multirow{5}{*}{,916 } \\
\hline & Hemşire & 104 & 233,07 & & & \\
\hline & İdari personel & 79 & 239,24 & & & \\
\hline & Sağlık teknikeri & 53 & 234,54 & & & \\
\hline & VHKİ & 160 & 223,78 & & & \\
\hline
\end{tabular}

Değerleme süreci boyutundaki farklılı̆̆ın veri hazırlama kontrol işletmeni (VHKİ) unvanında çalışanların özellikle hemşireler olmak üzere diğer unvanlarda (hekim, hemşire, idari personel, sağlık teknikeri) çalışanlara göre ortalamalarından $(\bar{x}(V H K I)=199,43<$ $\overline{\mathrm{x}}($ Hekim $)=264,46, \overline{\mathrm{x}}($ Hemşire $), 253,11, \overline{\mathrm{x}}$ (İdari personel) 232,94, $\overline{\mathrm{x}}$ (Sağllk teknikeri) $=$ $232,94)$ oldukça düşüktür. Değerlemeye bağlı ücret ve ödül boyutundaki farkl1lık nedeni ise hekim ortalamalarının ve VHKİ ortalamalarının hemşire ve sağlı teknikeri ortalamalarından düşük" ( " " ${ }^{\prime \prime}($ VHKI $)=219,17$, " " $x "-"$ " ("Hekim" $) "=210,44<$ " " $x^{\prime \prime-" ~}($ Hemşire $)=$ 256,38 , " " $x "$ " (Sağllk teknikeri = 258,74)" olmasıdır. 
Tablo 4. Performans değerleme algıs1- departman ilişkisi

\begin{tabular}{|c|c|c|c|c|c|c|}
\hline & Departman & $\mathrm{N}$ & $\begin{array}{c}\text { Ortalama } \\
\text { Sirası }\end{array}$ & $\begin{array}{c}\text { Serbestlik } \\
\text { derecesi }\end{array}$ & Ki kare & Sig. \\
\hline \multirow[t]{3}{*}{ Değerleme Süreci } & İdari ve mali hizmet & 172 & 221,52 & \multirow{3}{*}{2} & \multirow{3}{*}{3,770} & \multirow{3}{*}{, 152} \\
\hline & Laboratuvar ve görüntüleme hizmetleri & 53 & 262,15 & & & \\
\hline & Tibbi hizmetler & 237 & 231,89 & & & \\
\hline \multirow{3}{*}{$\begin{array}{l}\text { Değerleme } \\
\text { Standartları ve } \\
\text { Hedefleri }\end{array}$} & İdari ve mali hizmet & 172 & 219,82 & \multirow{3}{*}{2} & \multirow{3}{*}{7,279} & \multirow{3}{*}{,026 } \\
\hline & Laboratuvar ve görüntüleme hizmetleri & 53 & 276,08 & & & \\
\hline & Tibbi hizmetler & 237 & 230,01 & & & \\
\hline \multirow{3}{*}{$\begin{array}{l}\text { Değerleme Sonrası } \\
\text { Geribildirim }\end{array}$} & İdari ve mali hizmet & 172 & 226,70 & \multirow{3}{*}{2} & 3,326 & \multirow{3}{*}{, 190} \\
\hline & Laboratuvar ve görüntüleme hizmetleri & 53 & 262,81 & & & \\
\hline & Tibbi hizmetler & 237 & 227,98 & & & \\
\hline \multirow{3}{*}{$\begin{array}{l}\text { Değerlemeye Bağl1 } \\
\text { Ücret ve Ödül }\end{array}$} & İdari ve mali hizmet & 172 & 221,49 & \multirow{3}{*}{2} & 6,404 & \multirow{3}{*}{,041 } \\
\hline & Laboratuvar ve görüntüleme hizmetleri & 53 & 273,87 & & & \\
\hline & Tibbi hizmetler & 237 & 229,29 & & & \\
\hline \multirow{3}{*}{ İş Dizaynı } & İdari ve mali hizmet & 172 & 226,19 & \multirow{3}{*}{2} & 1,790 & \multirow{3}{*}{,409 } \\
\hline & Laboratuvar ve görüntüleme hizmetleri & 53 & 253,44 & & & \\
\hline & T1bbi hizmetler & 237 & 230,45 & & & \\
\hline
\end{tabular}

Performans değerleme süreci ve çalışanların hizmet verdikleri departmanlar arasında anlamlı bir farklılık bulunmuştur. Yapılan analiz sonucunda değerleme standartları ve hedefleri ile değerlemeye bağlı ücret ve ödül boyutlarında farklılık bulunmuştur $(\mathrm{p}<0,05)$. Laboratuvar ve görüntüleme hizmetleri departmanlarında çalışanların ortalamaları diğer iki departmana (idari ve mali hizmetler ve tıbbi hizmetler) göre oldukça yüksektir ( $\bar{x}$ (lab. ve görünt.) $=219,82<$ $\bar{x}($ İdari ve mali $)=276,08, \bar{x}($ Tıbbi hizm. $)=230,01)$. Performans değerleme sürecinden laboratuvar ve görüntüleme hizmetlerinde çalışanların diğer iki departman olan tıbbi ve idari ve mali hizmetler de çalışanlara oranla daha memnun ( $\bar{x}$ (lab.ve görünt.) $=$ $273,87>\bar{x}($ tıbbi hizm. $)=221,49, \bar{x}$ (idari ve mali $)=229,29)$ oldukları görülmüştür.

Performans değerleme sisteminde organizasyonlarda iki taraf vardır; değerlenen astlar ve değerlendiren yöneticiler. İki taraf arasında hem iş motivasyonu hem de performans değerleme sistemini algılama yönünden farklılık olabileceği varsayılmış ve bu farklılı̆̆ saptamak amaciyla performans değerleme boyutları ile iş motivasyonu boyutları ile yöneticiler ve astlar arasında Mann Whitney-U testi uygulanmıştır. Sonuçlar aşağıda verilmiştir.

Tablo 5. Performans algıs1- yöneticiler ve astlar arasında ilişkisi

\begin{tabular}{|c|c|c|c|c|c|}
\hline & Yöneticilik & $\mathrm{N}$ & Ortalama sırası & $\mathrm{Z}$ & Sig. \\
\hline \multirow{2}{*}{ Değerleme Sistemi } & Yönetici & 44 & 299,27 & \multirow{2}{*}{$-3,546$} & \multirow{2}{*}{, 000} \\
\hline & Ast & 418 & 224,37 & & \\
\hline \multirow{2}{*}{ Değerleme Standartları ve Hedefleri } & Yönetici & 44 & 299,59 & \multirow{2}{*}{$-3,563$} & \multirow{2}{*}{, 000} \\
\hline & Ast & 418 & 224,33 & & \\
\hline \multirow{2}{*}{ Değerleme Sonrası Geribildirim } & Yönetici & 44 & 251,67 & \multirow{2}{*}{$-1,057$} & \multirow{2}{*}{,290 } \\
\hline & Ast & 418 & 229,38 & & \\
\hline \multirow{2}{*}{ Değerlemeye Bağlı Ücret ve Ödül } & Yönetici & 44 & 301,60 & \multirow{2}{*}{$-3,671$} & \multirow{2}{*}{, 000} \\
\hline & Ast & 418 & 224,12 & & \\
\hline \multirow{2}{*}{ İş Dizaynı } & Yönetici & 44 & 245,31 & \multirow{2}{*}{,- 736} & \multirow{2}{*}{,462 } \\
\hline & Ast & 418 & 230,05 & & \\
\hline
\end{tabular}

$\overline{(p<0,05) .}$

Yapılan analiz sonucunda yöneticiler ve astları arasında değerleme sistemi, değerleme standartları ve hedefleri ile değerlemeye bağlı ücret ve ödül boyutlarında farklılık bulunmuştur. Her üç boyutta da farklılığın sebebi yöneticilerin ifadelere katılım oranlarının astların katılım oranlarına göre oldukça yüksek olmasıdır. Bu sonuç değerlendiren taraf olan yöneticilerin kendi yürüttükleri performans değerleme sisteminden astlara oranla daha memnun oldukları şeklinde yorumlanabilir. 
Tablo 6. Motivasyon-unvan ilişkisi

\begin{tabular}{|c|c|c|c|c|c|c|}
\hline & Unvan & $\mathrm{N}$ & $\begin{array}{c}\text { Ortalama } \\
\text { Siras1 }\end{array}$ & $\begin{array}{c}\text { Serbestlik } \\
\text { derecesi }\end{array}$ & Ki kare & Sign \\
\hline \multirow{5}{*}{ Kendini Değerleri Hissetme } & Hekim & 66 & 215,07 & \multirow{5}{*}{4} & \multirow{5}{*}{5,700} & \multirow{5}{*}{,223 } \\
\hline & Hemşire & 104 & 240,02 & & & \\
\hline & İdari personel & 79 & 221,21 & & & \\
\hline & Sağlık teknikeri & 53 & 265,77 & & & \\
\hline & VHKİ & 160 & 226,47 & & & \\
\hline \multirow{5}{*}{ Örgütsel Bağlılık } & Hekim & 66 & 221,79 & \multirow{5}{*}{4} & \multirow{5}{*}{13,083} & \multirow{5}{*}{, 011} \\
\hline & Hemşire & 104 & 244,23 & & & \\
\hline & İdari personel & 79 & 261,29 & & & \\
\hline & Sağlık teknikeri & 53 & 253,66 & & & \\
\hline & VHKİ & 160 & 205,18 & & & \\
\hline \multirow{5}{*}{ Ücret ve Ödüllendirme } & Hekim & 66 & 244,15 & \multirow{5}{*}{4} & \multirow{5}{*}{12,603} & \multirow{5}{*}{, 013} \\
\hline & Hemşire & 104 & 249,13 & & & \\
\hline & İdari personel & 79 & 259,48 & & & \\
\hline & Sağlık teknikeri & 53 & 218,71 & & & \\
\hline & VHKİ & 160 & 205,25 & & & \\
\hline \multirow{5}{*}{ Takım Çalışması } & Hekim & 66 & 218,28 & \multirow{5}{*}{4} & \multirow{5}{*}{7,823} & \multirow{5}{*}{,098 } \\
\hline & Hemşire & 104 & 242,51 & & & \\
\hline & İdari personel & 79 & 255,51 & & & \\
\hline & Sağlık teknikeri & 53 & 247,02 & & & \\
\hline & VHKİ & 160 & 212,80 & & & \\
\hline \multirow{5}{*}{$\begin{array}{c}\text { Çalışma Ortamının Fiziki } \\
\text { Durumu }\end{array}$} & Hekim & 66 & 198,82 & \multirow{5}{*}{4} & \multirow{5}{*}{7,998} & \multirow{5}{*}{,092 } \\
\hline & Hemşire & 104 & 224,60 & & & \\
\hline & İdari personel & 79 & 252,66 & & & \\
\hline & Sağlık teknikeri & 53 & 255,42 & & & \\
\hline & VHKİ & 160 & 231,09 & & & \\
\hline
\end{tabular}

Motivasyon boyutları ile sahip olunan unvanlar arasında anlamlı ilişki olup olmadığını belirlemek amacıyla da Kruskal Wallis testi yapılmıştır ve yapılan analizler sonucunda motivasyon boyutlarında örgütsel bağl1lık ve ücret ve ödüllendirme göre farklılık tespit edilmiştir $(p<0,05)$. Örgütsel bağlılık boyutunda VHKİ unvanında çalışanların diğer unvanlarda (hemşire, idari personel ve sağlık teknikeri) çalışanlara göre oldukça düşük $(\bar{x}(V H K \mathrm{I})=205,18<$ $\bar{x}($ hemşire $)=244,23, \bar{x}($ idari personel $)=261,29, \bar{x}($ sağllk teknikeri $)=253,66)$ ortalamalara sahip oldukları görülmüştür. Ücret ve ödüllendirme boyutunda ise VHKİ unvanında çalışanların diğer unvanlarda (hekim, hemşire, idari personel) göre ortalamalarının oldukça düşük $(\bar{x}($ VHKI $)=205,25<\bar{x}($ hekim $)=244,15, \bar{x}$ (hemşire $), 249,13, \bar{x}($ idari personel $)=$ $259,48)$ olduğu görülmüştür.

Tablo 7. Motivasyon-departman ilişkisi

\begin{tabular}{|c|c|c|c|c|c|c|}
\hline & Departman & $\mathrm{N}$ & $\begin{array}{l}\text { Ortalama } \\
\text { Sirası }\end{array}$ & $\begin{array}{l}\text { Serbestlik } \\
\text { derecesi }\end{array}$ & Ki kare & Sig. \\
\hline \multirow{3}{*}{$\begin{array}{c}\text { Kendini Değerli } \\
\text { Hissetme }\end{array}$} & İdari ve mali hizmet & 172 & 204,41 & \multirow{3}{*}{2} & 12,773 & \multirow{3}{*}{, 002} \\
\hline & Laboratuvar ve görüntüleme hizmetleri & 53 & 266,44 & & 12,113 & \\
\hline & Tibbi hizmetler & 237 & 243,34 & & & \\
\hline \multirow{3}{*}{ Örgütsel Bağlılık } & İdari ve mali hizmet & 172 & 220,99 & \multirow{3}{*}{2} & 2,512 & \multirow{3}{*}{, 285} \\
\hline & Laboratuvar ve görüntüleme hizmetleri & 53 & 252,38 & & & \\
\hline & Tibbi hizmetler & 237 & 234,46 & & & \\
\hline \multirow{3}{*}{$\begin{array}{c}\text { Ücret ve } \\
\text { Ödüllendirme }\end{array}$} & İdari ve mali hizmet & 172 & 243,48 & \multirow{3}{*}{2} & 6,924 & \multirow{3}{*}{, 031} \\
\hline & Laboratuvar ve görüntüleme hizmetleri & 53 & 260,29 & & & \\
\hline & Tibbi hizmetler & 237 & 216,37 & & & \\
\hline \multirow{3}{*}{ Takım Çalışması } & İdari ve mali hizmet & 172 & 229,40 & \multirow{3}{*}{2} & 3,140 & \multirow{3}{*}{,208 } \\
\hline & Laboratuvar ve görüntüleme hizmetleri & 53 & 261,70 & & & \\
\hline & Tibbi hizmetler & 237 & 226,27 & & & \\
\hline \multirow{3}{*}{$\begin{array}{l}\text { Çalışma Ortamının } \\
\text { Fiziki Durumu }\end{array}$} & İdari ve mali hizmet & 172 & 239,56 & \multirow{3}{*}{2} & 1,619 & \multirow{3}{*}{,445 } \\
\hline & Laboratuvar ve görüntüleme hizmetleri & 53 & 213,83 & & & \\
\hline & Tibbi hizmetler & 237 & 229,60 & & & \\
\hline
\end{tabular}

$(p<0,05)$.

Çalışılan departman ile motivasyon arasında farklılık olup olmadığını anlamak için yapılan Kruskal Wallis testi sonucunda kendini değerli hissetme faktörü ile ücret ve ödüllendirme faktörlerinde istatistiki olarak anlamlı farklılık bulunmuştur $(\mathrm{p}<0,05)$. Kendini değerli hissetme 
faktörünün altında idari ve mali hizmetlerde çalışanların ortalamaları diğer iki departman olan laboratuvar ve görüntüleme hizmetleri ile tıbbi hizmetleri departmanlarında çalışanlara göre oldukça düşüktür $(\bar{x}$ (idari ve mali hizm. $)=266,44<\bar{x}$ (lab.ve görünt.hizm. $)=$ $266,44, \bar{x}(t$ tbbi hizm. $)=243,34)$. Ücret ve ödüllendirme faktöründe ise tıbbi hizmetler departmanında çalışanların ortalamaları idari ve mali hizmetler ile laboratuvar ve görüntüleme hizmetlerinde çalışanlara göre oldukça düşük $(\bar{x}$ (tıbbi hizm. $)=$ $216,37 \bar{x}$ (lab.ve görünt. hizm. $)=243,48, \bar{x}$ (idari ve mali $)=260,29) \quad$ kaldığ 1 görülmüş̧ür.

Yöneticiler ve astlar arasında motivasyon boyutları açısından bakıldığında ise örgütsel bağllık, ücret ve ödüllendirme, takım çalışması ile çalışma ortamının fiziki durumu boyutlarında farklılık bulunmuştur (Tablo 10). Performans değerleme sistemi boyutlarında olduğu gibi iş motivasyonu boyutlarında da farklılık yöneticilerin katılım oranlarının astlara göre oldukça yüksek olmasıdır.

Tablo 8. Motivasyon - yöneticiler ve astlar arasında ilişkisi

\begin{tabular}{|c|c|c|c|c|c|}
\hline & Yöneticilik & $\mathrm{N}$ & Ortalama sırası & $\mathrm{Z}$ & Sig. \\
\hline \multirow{2}{*}{ Kendini Değerli Hissetme } & Yönetici & 44 & 253,74 & \multirow{2}{*}{$-1,171$} & \multirow{2}{*}{,242 } \\
\hline & Ast & 418 & 229,16 & & \\
\hline \multirow{2}{*}{ Örgütsel Bağlılık } & Yönetici & 44 & 296,10 & \multirow{2}{*}{$-3,398$} & \multirow{2}{*}{,001 } \\
\hline & Ast & 418 & 224,70 & & \\
\hline \multirow{2}{*}{ Ücret ve Ödüllendirme } & Yönetici & 44 & 269,05 & \multirow{2}{*}{$-1,965$} & \multirow{2}{*}{,049 } \\
\hline & Ast & 418 & 227,55 & & \\
\hline \multirow{2}{*}{ Takım Çalışması } & Yönetici & 44 & 282,27 & \multirow{2}{*}{$-2,662$} & \multirow{2}{*}{,008 } \\
\hline & Ast & 418 & 226,16 & & \\
\hline \multirow{2}{*}{$\begin{array}{c}\text { Çalışma Ortamının Fiziki } \\
\text { Durumu }\end{array}$} & Yönetici & 44 & 295,28 & \multirow{2}{*}{$-3,348$} & \multirow{2}{*}{,001 } \\
\hline & Ast & 418 & 224,79 & & \\
\hline
\end{tabular}
$(\mathrm{p}<0,05)$.

Çalışmanın ana amaçlarından biri olan kamu ve özel hastanelerin çalışanları arasında performans değerleme sistemine ilişkin düşünceler ve motivasyon açısından farkl1lık bulunup bulunmadığını tespit etmek amacıyla ("H3: Performans değerleme boyutlarına ilişkin çalışan görüşleri kamu, özel ve üniversite hastaneleri arasında farklılık göstermektedir." ve "H4: Motivasyon boyutlarına ilişkin çalışan görüşleri kamu, özel ve üniversite hastaneleri arasında farklılık göstermektedir.") "Kruskal Wallis" testleri gerçekleştirilmiştir (Tablo 9 ve Tablo 10).

Tablo 9. Performans değerleme hastane ilişkisi

\begin{tabular}{|c|c|c|c|c|c|c|}
\hline & Hastane & $\mathrm{N}$ & $\begin{array}{c}\text { Ortalama } \\
\text { Sirası }\end{array}$ & $\begin{array}{c}\text { Serbestlik } \\
\text { derecesi }\end{array}$ & Ki kare & Sig. \\
\hline \multirow[t]{3}{*}{ Değerleme Süreci } & Devlet Hastanesi & 100 & 220,98 & \multirow{3}{*}{2} & \multirow{3}{*}{11,422} & \multirow{3}{*}{,003 } \\
\hline & Üniversite Hastanesi & 270 & 221,08 & & & \\
\hline & Özel Hastane & 92 & 273,52 & & & \\
\hline \multirow{3}{*}{$\begin{array}{c}\text { Değerleme Standartları ve } \\
\text { Hedefleri }\end{array}$} & Devlet Hastanesi & 100 & 215,94 & \multirow{3}{*}{2} & 20,757 & \multirow{3}{*}{, 000} \\
\hline & Üniversite Hastanesi & 270 & 217,97 & & & \\
\hline & Özel Hastane & 92 & 288,13 & & & \\
\hline \multirow{3}{*}{$\begin{array}{l}\text { Değerleme Sonrası } \\
\text { Geribildirim }\end{array}$} & Devlet Hastanesi & 100 & 201,76 & \multirow{3}{*}{2} & 7,859 & \multirow{3}{*}{, 020} \\
\hline & Üniversite Hastanesi & 270 & 234,75 & & & \\
\hline & Özel Hastane & 92 & 254,28 & & & \\
\hline \multirow{3}{*}{$\begin{array}{c}\text { Değerlemeye Bağlı Ücret } \\
\text { ve Ödül }\end{array}$} & Devlet Hastanesi & 100 & 246,29 & \multirow{3}{*}{2} & \multirow{3}{*}{17,579} & \multirow{3}{*}{,000 } \\
\hline & Üniversite Hastanesi & 270 & 211,07 & & & \\
\hline & Özel Hastane & 92 & 275,38 & & & \\
\hline \multirow{3}{*}{ İş Dizaynı } & Devlet Hastanesi & 100 & 226,06 & \multirow{3}{*}{2} & \multirow{3}{*}{,229 } & \multirow{3}{*}{, 892} \\
\hline & Üniversite Hastanesi & 270 & 232,63 & & & \\
\hline & Özel Hastane & 92 & 234,09 & & & \\
\hline
\end{tabular}

Yapılan analiz sonucunda performans değerleme sistemi boyutlarından değerleme süreci, değerleme standartları ve hedefleri, değerleme sonrası geribildirim ve değerlemeye bağlı ücret ve ödül boyutları için hastaneler arasında istatistiki olarak anlamlı farklılık bulunmuştur $(p<0,05)$. Değerleme süreci faktöründeki farklılığın sebebi Özel Hastane'nin çalışanlarının Üniversite Hastanesi ile Devlet Hastanesi çalışanlarına göre ortalamalarının oldukça yüksek $(\bar{x}=273,52>\bar{x}=221,08, \bar{x}=$ 220,98 ) olmasıdır. Değerleme standart ve hedefleri faktöründe de farklılığın sebebi Özel Hastane'nin çalş̧anlarının Üniversite Hastanesi ile Devlet Hastanesi çalışanlarına göre ortalamalarının oldukça 
yüksek ( $\bar{x}=288,13>\bar{x}=217,97, \bar{x}=215,94)$ olmasıdır. Değerleme sonrası geribildirim faktöründeki farklılığın sebebi ise Devlet Hastanesi çalışanlarının Özel Hastane ve Üniversite Hastanesi çalışanlarına göre ortalamalarının oldukça düşük $(\bar{x}=201,76<\bar{x}=234,75, \bar{x}=254,28)$ kalmasıdır. Değerlemeye bağlı ücret ve ödül faktöründe ise Üniversite Hastanesi çalışanları diğer iki hastane olan Devlet Hastanesi ile Özel Hastane çalışanlarına göre düşük $(\bar{x}=211,07<\bar{x}=$ $246,29, \bar{x}=275$,38) kalmıştır. Buna göre, "H3: Performans değerleme boyutlarına ilişkin çalışan görüşleri kamu, özel ve üniversite hastaneleri arasında farklılık göstermektedir.” Hipotezi iş dizaynı boyutu dışında tüm boyutlarda kabul edilmiştir.

Motivasyon boyutları açısından hastaneler arasında fark olup olmadığını anlamak için yapılan Kruskal Wallis testi sonuçları Tablo 10'da sunulmuştur.

Tablo 10. Motivasyon- hastane ilişkisi

\begin{tabular}{|c|c|c|c|c|c|c|}
\hline & Hastane & $\mathrm{N}$ & $\begin{array}{c}\text { Ortalama } \\
\text { Sirası }\end{array}$ & $\begin{array}{c}\text { Serbestlik } \\
\text { derecesi }\end{array}$ & Ki kare & Sig. \\
\hline \multirow{3}{*}{ Kendini Değerli Hissetme } & Devlet Hastanesi & 100 & 196,90 & \multirow{3}{*}{2} & \multirow{3}{*}{12,781} & \multirow{3}{*}{, 002} \\
\hline & Üniversite Hastanesi & 270 & 232,86 & & & \\
\hline & Özel Hastane & 92 & 265,13 & & & \\
\hline \multirow{3}{*}{ Örgütsel Bağlılık } & Devlet Hastanesi & 100 & 205,42 & \multirow{3}{*}{2} & \multirow{3}{*}{6,299} & \multirow{3}{*}{,043 } \\
\hline & Üniversite Hastanesi & 270 & 233,96 & & & \\
\hline & Özel Hastane & 92 & 252,64 & & & \\
\hline \multirow{3}{*}{ Ücret ve Ödüllendirme } & Devlet Hastanesi & 100 & 206,06 & \multirow{3}{*}{2} & \multirow{3}{*}{4,675} & \multirow{3}{*}{,097 } \\
\hline & Üniversite Hastanesi & 270 & 237,93 & & & \\
\hline & Özel Hastane & 92 & 240,27 & & & \\
\hline \multirow{3}{*}{ Takım Çalışması } & Devlet Hastanesi & 100 & 197,75 & \multirow{3}{*}{2} & \multirow{3}{*}{10,180} & \multirow{3}{*}{,006 } \\
\hline & Üniversite Hastanesi & 270 & 235,11 & & & \\
\hline & Özel Hastane & 92 & 257,60 & & & \\
\hline \multirow{3}{*}{$\begin{array}{c}\text { Çalışma Ortamının Fiziki } \\
\text { Durumu }\end{array}$} & Devlet Hastanesi & 100 & 231,39 & \multirow{3}{*}{2} & \multirow{3}{*}{38,563} & \multirow{3}{*}{, 000} \\
\hline & Üniversite Hastanesi & 270 & 206,22 & & & \\
\hline & Özel Hastane & 92 & 305,82 & & & \\
\hline
\end{tabular}

$(p<0,05)$.

Yapılan analiz sonucunda kendini değerleme hissetme, örgütsel bağlılık, takım çalışması ve çalışma ortamının fiziki durumu boyutları için hastaneler arasında anlamlı farklılık bulunmuştur $(\mathrm{p}<0,05)$. Kendini değerli hissetme faktöründeki farklılığın sebebinin Devlet Hastanesi çalışanlarının Üniversite Hastanesi ile Özel Hastane çalışanlarına göre düşük $(\bar{x}=196,90<\bar{x}=232,86, \bar{x}=$ $265,13)$ kalmasıdır. Örgütsel bağl1lık faktöründe de farklılığın sebebi Devlet Hastanesi çalışanlarının Üniversite Hastanesi ile Özel Hastane çalışanlarına göre düşük $(\bar{x}=205,42<\bar{x}=233,96, \bar{x}=$ $252,64)$ kalmasıdır. Yine aynı şekilde takım çalışması faktöründe de farklıı̆ı̆ın sebebi Devlet Hastanesi çalışanlarının Üniversite Hastanesi ile Özel Hastane çalışanlarına göre düşük $(\bar{x}=197,75<\bar{x}=$ $235,11, \bar{x}=257,60)$ kalmasıdır. Çalışma durumunun fiziki durumu faktörüne bakıldığında ise Özel Hastane çalışanlarının ortalamalan kamu hastaneleri olan Üniversite Hastanesi ve Devlet Hastanesi çalışanlarına göre oldukça yüksek ( $\bar{x}=305,82>\bar{x}=206,22, \bar{x}=231,39)$ olduğu görülmüştür. Buna göre, "H4: Motivasyon boyutlarına ilişkin çalışan görüşleri kamu, özel ve üniversite hastaneleri arasında farklılık göstermektedir." Hipotezi ücret ve ödüllendirme dışındaki tüm boyutlarda kabul edilmiştir.

Performans değerleme sisteminin her bir faktörü ile motivasyon faktörleri arasındaki ilişskinin açıklanması için Spearman's Rho Korelasyon Testi boyutlar arasında yapılmış ve aralarındaki ilişki açıklanmaya çalışılmıştır (Tablo 11). 
Tablo 11. Performans değerleme süreci ve motivasyon ilişkisi

\begin{tabular}{|c|c|c|c|c|c|}
\hline & $\begin{array}{l}\text { Kendini Değerli } \\
\text { Hissetme }\end{array}$ & $\begin{array}{l}\text { Örgütsel } \\
\text { Bağlılık }\end{array}$ & $\begin{array}{l}\text { Ücret ve } \\
\text { Ödül }\end{array}$ & Takım Çalışması & $\begin{array}{c}\text { Çalışma } \\
\text { Ortamının Fiziki } \\
\text { Durumu }\end{array}$ \\
\hline $\begin{array}{l}\text { Değerleme } \\
\text { Süreci }\end{array}$ &, $342^{* * *}$ & $556^{* *}$ & $550^{* *}$ & $570^{* *}$ & $493^{* *}$ \\
\hline $\begin{array}{c}\text { Değerleme } \\
\text { Standartları } \\
\text { ve Hedefleri }\end{array}$ &, $506^{* *}$ &, $509^{* *}$ &, $331^{* *}$ &, $608^{* *}$ &, $510^{* *}$ \\
\hline $\begin{array}{c}\text { Değerlemeye } \\
\text { Bağlı Ücret } \\
\text { ve Ödül }\end{array}$ &, $133^{* *}$ &, $348^{* *}$ &, $602^{* *}$ &, $355^{* *}$ &, $312^{* *}$ \\
\hline $\begin{array}{l}\text { Değerlemeye } \\
\text { Bağlı } \\
\text { Geribildirim }\end{array}$ &, $361^{* *}$ &, $523^{* * *}$ &, $481^{* *}$ &, $589^{* * *}$ &, $556^{* *}$ \\
\hline İş Dizaynı &, 111 & ,293 &, 354 & ,343 & ,316 \\
\hline
\end{tabular}

Tablo 11 incelendiğinde, performans değerleme boyutları ile motivasyon boyutları arasında pozitif yönlü anlamlı bir ilişki olduğu görülmektedir. Performans değerleme ölçeğinin alt boyutları olan değerleme süreci, değerleme standartları ve hedefleri, değerlemeye bağlı ücret ve ödül, değerlemeye bağlı geribildirim ve iş dizaynı ile motivasyon alt boyutları, kendini değerli hissetme, örgütsel bağlılık, ücret ve ödül, takım çalışması ve çalışma ortamının fiziki durumu arasında anlamlı ve pozitif bir ilişki bulunmuştur. Bu sonuçlara göre performans değerleme ortalamaları yükseldikçe motivasyon ortalamaları da yükselmektedir. "H5: Performans değerleme boyutları ile motivasyon boyutları arasında bir ilişki vardır." Hipotezi kabul edilmiştir.

\section{Sonuç ve Öneriler}

Performans değerleme sisteminin adil ve standart faktörlere sahip olması ve adil ve standart kriterler ile ölçülmesi, sonuçların çalışanlara geri dönüt olarak verilmesi çalışanları motive eder. Son zamanlarda yapılan pek çok çalışma incelendiğinde; örgütlerde çalışan performans değerlendirme sistemindeki anlayışın değiştiğine yönelik birçok çalışma yapıldığ görülecektir. $\mathrm{Bu}$ çalışmalarda performans yönetimi ile motivasyon arasında ilişkiye ağırlık verilmektedir.

Yapılan çalışma sonucunda ortaya çıkan beş performans değerleme ve beş motivasyon boyutunda sosyo-demografik özelliklere göre anlamlı bir farklılık olup olmadığı hipotezler test edilerek incelenmiştir. "H1: Çalışanların performans değerleme sistemlerine iliş̧in görüşleri demografik özelliklerine göre farklılık göstermektedir." hipotezi test edilmiş ve kısmen kabul edilmiş ve şu sonuçlara ulaşılmıştır; çalışanların sahip oldukları unvanlara bakıldığında, VHKİ kadrosunda çalışanların diğer unvanlara (hekim, hemşire, idari personel ve sağlık teknikeri) sahip çalışanlara göre ortalamaların oldukça düşük olduğu görülmüştür. Performans değerleme konusunda laboratuvar ve görüntüleme hizmetleri departmanında görev yapan çalışanların diğer departmanlarda (İdari ve mali hizmetler ile tıbbi hizmetler) görev yapan çalışanlara göre katılımları daha yüksek olduğundan bu departmanda görev yapanların performans değerleme sisteminden daha fazla memnun oldukları düşünülmektedir. Çalışanların yöneticilik pozisyonuna sahip olmaları da anlamlı bir farklılık yaratmıştır. Sonuçlara göre yöneticilerin ortalamaları astlarının ortalamalarından daha yüksektir. Kendi yürüttükleri performans değerleme sisteminden yöneticilerin astlarına oranla daha memnun oldukları ortaya konulmuştur.

"H2: Çalışanların motivasyonları demografik özelliklerine göre farklılık göstermektedir." Hipotezi kısmen kabul edilmiştir. Sonuçlara bakıldığında; VHKİ kadrosunda görev yapan çalışanların motivasyon boyutlarına katılım ortalamaları diğer unvanlarda çalışanlara göre 
oldukça düşük kalmıştır. Kendini değerli hissetme alt boyutunda idari ve mali hizmetlerde çalışanların diğer iki departman (Tıbbi hizmetler ile laboratuvar ve görüntüleme hizmetleri) çalışanlarına göre ortalamaları oldukça düşük kalmıştır. Diğer taraftan ücret ve ödüllendirme alt boyutunda ise tıbbi hizmetlerde çalışanların ortalamaları diğer departmanlarda çalı̧̧anlara göre düşük kalmıştır. Performans değerleme algısı ile paralel olarak yöneticilerin motivasyon ortalamaları yönetici pozisyonunda olmayan çalışanlara göre oldukça yüksek bulunmuştur.

"H3: Performans değerleme boyutlarına ilişkin çalışan görüşleri kamu, özel ve üniversite hastaneleri arasında farklılık göstermektedir." hipotezi kabul edilmiştir. Özel hastane çalışanları ile kamu hastaneleri olan devlet hastanesi ve üniversite hastanesi çalışanlarına oranla performans değerleme sisteminin işleyişinden oldukça memnun oldukları görülmüştür. Özel sektörde çalışanların performanslarının getirisi (ücret zamı, prim, terfi vb.) ve performanslarına bağlı olarak tam aksi kararlar (işten çıkarılma, terfinin düşürülmesi vb.) çok daha anlamlı ve sistemli bir şekilde ilerlemekte olduğu belirlenmiştir.

"H4: Motivasyon boyutlarına ilişkin çalışan görüşleri kamu, özel ve üniversite hastaneleri arasında farklı1ık göstermektedir." Hipotezi kabul edilmiştir. Performans değerleme sistemi algısına paralel olarak özel sektör çalışanlarının motivasyon ortalamaları oldukça yüksektir. "H5: Performans değerleme boyutları ile motivasyon boyutları arasında bir ilişki vardır." Hipotezi kabul edilmiştir. Tüm sonuçlar değerlendirildiğinde çalışmada performans değerleme ile motivasyon arasındaki pozitif yönlü bir ilişki olduğu kabul edilmiştir.

Tüm sonuçlar 1şığında çalışmada sunulacak olan bir öneri ise; performans değerleme sisteminin ne kadar adil, düzenli ve verimli olursa çalışan motivasyonun da o kadar artacağı ve çalışanlardan daha fazla verim alınacağı yönünde olacağıdır. Düzgün işleyen bir performans değerleme sisteminin etkinliği çalışan motivasyonunu olumlu olarak etkilediği, bunun tersi durumunda ise çalışanın performansı doğru ölçülemeyen bireylerin motivasyon ve dolayısıyla performanslarının da düşmeye başlayacağından gereken önemin verilmesi oldukça önemlidir. Ayrıca kadro/unvana bakıldığında kadrosu veri hazırlama kontrol işletmeni olan çalışanların performans değerleme sisteminden özellikle ücret ve ödül boyutunda yeterince yararlanamadığ 1 ve performans değerleme sisteminin işleyişinden memnun olmadıkları ortaya çıkmıştır. Disiplin sistemi, başka bir deyişle ödül ve ceza sistemi kurulmalı ve hakkaniyet ilkesi doğrultusunda işletilmeli ve tüm kadro/unvana sahip çalışanlar memnun edilmelidir. Çalışmanın sonuçlarından biri de idari personel ile tıbbi kadrolarda yer alan personelin motivasyon kaynaklarının birbirinden farklı olduğunun anlaşılmasıdır. Tıbbi kadrolarda yer alan çalışan kendini değerli hissetme ihtiyacı duymazken, idari personel ise ücret ve ödül konusunda tıbbi kadrolarda yer alan çalışanlar kadar ihtiyaç duymamaktadır. Bu durum özellikle yöneticilerin çalışan motivasyonu göz önüne alındığında farklı motive kaynaklarını dikkate almaları gerektiğini açığa çıkarmıştır. Sadece içsel ya da sadece dışsal motivasyon kaynaklarına yönelmek hem çalışan hem de yönetici ve kurum için istenen başarıyı sağlamaya yeterli olmayacaktır. Özel sağlık kuruluşlarında etkin bir şekilde yürütüldüğü belirlenen performans değerleme sisteminin kamu sağlık kuruluşlarında da etkin bir şekilde yürütülmesi için gerekli olan düzenlemeler yapılmalıdır. Araştırma kapsamı Çankaya ilçesinde hizmet vermekte olan bir üniversite, bir devlet ve bir özel hastane ile sınırlı tutulmuş olup, performans değerleme ile motivasyon arasındaki ilişki hem çalışan hem de hasta ve hasta yakınları açılarından daha geniş bir örneklem seçilip daha kapsamlı bir çalışma yapılabilir.

\section{Kaynakça}

Ağırbaş, İ., Çelik, Y. ve Büyükkayıkçı, H. (2005). Motivasyon araçları ve iş tatmini: sosyal sigortalar kurumu başkanlığ 1 hastane başhekim yardımcıları üzerinde bir araştırma. Hacettepe Să̆llk İdaresi Dergisi, 8(3), 326-350.

Aletras, V., Kontodimopoulos, N., Zagouldoudis, A. and Niakas, D. (2007). The short-term effect on technical and scale efficiency of establishing regional health systems and general 
management in Greek NHS hospitals, Health Policy, 83(2-3), 36-45, doi: 10.1016/j.healthpol.2007.01.008.

Alkış, H. (2008). Üretim işletmeleri açısından iş görenlerin demografik özellikleri ile motivasyon araçlarını algılama düzeyleri arasındaki ilişki. Кати-I̧ş Dergisi, 10(2), 79-96.

Argon, T. ve Eren, A. (2004). Insan kaynakları yönetimi. Ankara: Nobel Basımevi.

Armstrong, M. (2010). Armstorng's essential human resource management practice: a guide to people management. United Kingdom: Kogan Page Limited.

Barutçugil, İ. (2004). Stratejik insan kaynakları yönetimi. İstanbul: Kariyer Yayınc1lık.

Bayrakçı, E. (2010). Lider davranışlarının çalışan motivasyonu üzerine etkisi: ipliksan aş bir araştırma", Süleyman Demirel Üniversitesi Vizyoner Dergisi, 2(2), 15-32.

Berdud, M., Cabasés, J. M., and Nieto, J. (2016). Incentives and intrinsic motivation in healthcare. Gaceta sanitaria, 30, 408-414, doi:10.1016/j.gaceta.2016.04.013.

Brooks I. (2006). Organizational behaviour (individuals, groups and organization), (3th Edition). United Kingdom: Pearson.

Camardella, M. J. (2003). Effective management of the performance-appraisal process. Employment Relations Today, 30(1), 103-106, doi:10.1002/ert.10080.

Can, H., Aşan, Ö. ve Miski, E. (2006). Örgütsel davranış. İstanbul: Arıkan Basım.

Can, H., Kavuncubaşı Ş. ve Yıldırım S. (2009). Kamu ve özel kesimde insan kaynakları yönetimi. (Altınc1 Bask1). Ankara: Siyasal Kitabevi.

Çağan, S.N. (2012). Performans ve motivasyon arasındaki ilişki: GATA hemşirelik hizmetleri örneği (Yayımlanmamış yüksek lisans tezi). Atılım Üniversitesi, Ankara.

Elliot, A. J. And Covington, M. V. (2001). Approach and avoidance motivation. Educational Psychology Review, 13(2), 73-92, doi.org/10.1023/A:1009009018235.

Ergin, G. (2012). Performans değerleme ile motivasyon arasındaki ilişki ve belediye çalışanları üzerine bir uygulama (Yayımlanmamış yüksek lisans tezi). İstanbul Aydın Üniversitesi, İstanbul.

Filizöz, B. (2003). İnsan kaynakları yönetiminde uluslararası yaklaşım gerekliliği. Cumhuriyet Üniversitesi İktisadi ve İdari Bilimler Dergisi, 4(1), 161-180.

Gök, S. (2009). Örgüt ikliminin çalışanların motivasyonuna etkisi üzerine bir araştırma. Uluslararası İnsan Bilimleri Dergisi, 6(2), 587-605.

Gu, X., and Itoh, K. (2016). Performance indicators: healthcare professionals' views. International journal of health care quality assurance, 29(7), 801-815, doi: 10.1108/IJHCQA-12-2015-0142.

Helvacı, M. A. (2002). Performans yönetim sürecinde performans değerlemenin önemi. Ankara Üniversitesi Eğitim Bilimleri Fakültesi Dergisi, 35(1-2),155-169.

Hiriyappa, B. (2008). Organization behavior. New Delhi-India: New Age International.

İlsev, A. (2016). İnsan kaynakları yönetiminde performans yönetimi ve değerlendirmesi. A. Ergeneli (Ed), İnsan Kaynakları Yönetimi içinde (ss. 177-205). Ankara: Nobel Yayınevi.

Jackson, J. H. and Mathis, R. L. (2011). Human resource management. (13th Edition). United States of America: South Western Congage Learning.

Karahan A. ve Özgür E. (2011). Hastanelerde performans yönetim sistemi ve veri zarflama analizi. (İkinci Baskı). Ankara: Nobel Kitabevi. 
Kılıç, R. ve Keklik, B. (2012). Sağlık çalışanlarında iş yaşam kalitesi ve motivasyona etkisi üzerine bir araştırma. Journal of Economics and Administrative Sciences/Afyon Kocatepe Üniversitesi İktisadi ve İdari Bilimler Fakültesi Dergisi, 14(2), 147-158.

Mathis R.L. and Jackson, J. H. (2011). Human resource management: Essential perspectives. Canada: South Western Congage Learning.

Ölçer, F. (2005). Departmanlı mağazalarda motivasyon üzerine bir araştırma. Erciyes Üniversitesi Iktisadi ve İdari Bilimler Fakültesi Dergisi, 25, 1-22.

Özer, M. ve Bakır, B. (2003). Sağlık personelinin motivasyonla ilgili etmenlerinin belirlenmesi. Gülhane Tip Dergisi. 45(2), 117-122.

Özgen, H., Öztürk, A., Yalçın, A. (2005). İnsan kaynakları yönetimi. Adana: Nobel Kitabevi.

Öztürk, N., Uysal, Ş. A., ve Çelik, R. (2016). Hospital managers' opinions about performance measurement in their registered hospitals: Antalya sample. Social Sciences, 1, 622-633, http://dx.doi.org/10.17740/eas.soc.2016.MSEMP-50

Palmer, M.J. (1993). Performans değerlendirmeleri. (D. Şahiner, Çev.). İstanbul: Rota Yayını.

Pardee, R. L. (1990). Motivation theories of maslow, herzberg, mcgregor \& mcclelland. a literature review of selected theories dealing with job satisfaction and motivation. http://files.eric.ed.gov/fulltext/ED316767.pdf, (Erişim tarihi: 12.02.2019).

Paşamehmetoğlu, A. ve Yeloğlu H.O. (2016). Motivasyon. S. Ünsal ve S. Gürbüz (Ed), Örgütsel Davranış içinde (ss. 137-174). İstanbul: Beta.

Pritchard, R. and Ashwood, E. (2008). Managing motivation: a manager's guide to diagnosing and improving motivation. United States of America: Routledge

Sabuncuoğlu, Z. (2005). İnsan kaynakları yönetimi (uygulamalı). (İkinci Baskı). Bursa: Furkan Ofset.

Schermerhorn J.R., Hunt J.G. and Osborn R.N. (2002). Organizational behavior. (7th Edition). United States of America: Wiley.

Scott, T., Mannion, R., Davies, H., and Marshall, M. (2018). Healthcare performance and organisational culture. United Kingdom: CRC Press.

Shah, S. M., Zaidi, S., Ahmed, J., and Rehman, S. U. (2016). Motivation and retention of physicians in primary healthcare facilities: a qualitative study from Abbottabad, Pakistan. International journal of health policy and management,5(8), 467-475, doi: 10.15171/ijhpm.2016.38.

Tarakçıŏlu, S., Sökmen, A., ve Boylu, Y. (2010). Motivasyon araçlarının değerlendirilmesi: Ankara' da bir araştırma. İşletme Araştırmaları Dergisi, (1), 3-20.

Tortop, N., Aykaç B., Yayman H. ve Özer M. (2007). İnsan kaynaklarl yönetimi, (2.Baskı). Ankara: Nobel.

Uyargil C. (2013a). Performans yönetimi. (İ.Ü. İşletme Fakültesi İnsan Kaynakları Anabilim Dalı Öğretim Üyeleri (Ed), İnsan Kaynakları Yönetimi içinde (ss. 212-264). İstanbul: Beta.

Uyargil C. (2013b). Performans yönetim sistemi bireysel performansın planlanması ve değerlendirilmesi ve geliştirilmesi. İstanbul: Beta.

Wiersma, U. J. (1992). The effects of extrinsic rewards in intrinsic motivation: a meta-analysis. Journal of Occupational and Organizational Psychology, 65(2), 101-114.

William, B., Werther, J., and Davis, K. (1996). Human resource and ersonnel management. United States of America: McGraw-Hill Inc. 
Wiley, C. (1997). What motivates employees according to over 40 years of motivation surveys. International Journal of Manpower, 18(3), 263-280.

\section{ETIK ve BİLIMSEL İLKELER SORUMLULUK BEYANI}

$\mathrm{Bu}$ çalışmanın tüm hazırlanma süreçlerinde etik kurallara ve bilimsel atıf gösterme ilkelerine riayet edildiğini yazar(lar) beyan eder. Aksi bir durumun tespiti halinde Afyon Kocatepe Üniversitesi Sosyal Bilimler Dergisi'nin hiçbir sorumluluğu olmayıp, tüm sorumluluk makale yazarlarına aittir. Yazarlar etik kurul izni gerektiren çalışmalarda, izinle ilgili bilgileri (kurul adı, tarih ve sayı no) yöntem bölümünde ve ayrıca burada belirtmişlerdir.

Kurul adı: Gazi Üniversitesi Etik Komisyonu

Tarih: 15.11.2016

No: E. 137171 